ABDIMAS: Jurnal Pengabdian Masyarakat Universitas Merdeka Malang
Vol.6(2) May 2021, 176-185
L-ISSN: 2721-138X e-ISSN: 2548-7159
http://jurnal.unmer.ac.id/index.php/jpkm

\title{
Penyuluhan bagi Masyarakat Peduli Sampah Polimer Termoplastik Kelurahan Rampal Celaket Kecamatan Klojen Kota Malang
}

\author{
Djoko Andrijono, Sufiyanto Sufiyanto \\ Departemen Teknik Mesin, Fakultas Teknik, Universitas Merdeka Malang \\ Jl. Terusan Raya Dieng No. 62-64 Malang 65146, Indonesia
}

\begin{abstract}
ARTICLE INFO ABSTRACT
Received: 2020-12-09 The workshop delivered to the anti-waste activists in Kelurahan Rampal Celaket, Kecamatan Klojen, Revised: 2021-02-15 Malang, is a community service program initiated by the Mechanical Engineering Department, Faculty Accepted: 2021-03-21 of Engineering University of Merdeka Malang in collaboration with the Research and Community Service of IKIP Budi Utomo Malang. Plastic products caused environmental issues due to its slow decomposition rate by microorganisms, especially after being disregarded or buried in the ground. Even though the movement to reduce the use of plastic has been widely promoted, Indonesians in general do not have enough understanding of the environmental problems caused by plastic waste. In addition, the public also lacks the understanding of several other matters, including a) the properties of thermoplastic and thermosetting polymers, b) the alternative ways to reuse plastic waste as handicrafts or plastic pellets as secondary materials for plastic products. The results of preliminary observation indicated that the community need a workshop program on plastic waste management, types of recyclable plastic, and the impact of reusing plastic waste through lecture and discussion methods. This counseling reveals that a workshop program with lecture and discussion methods could increase public knowledge and awareness on plastic waste processing.
\end{abstract}

(C)2021 Published by University of Merdeka Malang. This is an open access article distributed under the CC BY-SA 4.0 license

(https://creativecommons.org/licenses/by-sa/4.0/)

How to cite: Andrijono, D., \& Sufiyanto, S. (2021). Penyuluhan bagi Masyarakat Peduli Sampah Polimer Termoplastik Kelurahan Rampal Celaket Kecamatan Klojen Kota Malang. Abdimas: Jurnal Pengabdian Masyarakat Universitas Merdeka Malang, 6(2), 176-185. https://doi.org/10.26905/abdimas.v6i2.5136

\section{PENDAHULUAN}

Plastik (plastic) merupakan material bukan logam termasuk jenis makro molekul yang dibentuk dengan proses polimerisasi atau plastik merupakan senyawa polimer dengan unsur penyusun utamanya karbon dan hidrogen (Malcolm, 2001). Polimerisasi merupakan proses penggabungan beberapa molekul sederhana (monomer) melalui proses kimia menjadi molekul besar (polimer atau makro molekul) 
(Hendrastianto, 2019; Odian, 1991). Berbagai macam produk plastik yang diproduksi oleh industri plastik seperti: gelas, botol, kantong kresek pembungkus, alat makan, kantong kemasan makanan. Produk-produk tersebut, setelah dipakai dibuang ke lingkungan seperti, sungai, laut, dan daratan berpotensi mencemari lingkungan karena sulit untuk diurai oleh mikro organisme saat dibuang ke tanah dan akan membuat penurunan populasi fauna tanah akibat menurunnya mineral, baik organik maupun anorganik di dalam tanah. Fauna tanah akan sulit mendapatkan oksigen $\left(\mathrm{O}_{2}\right)$ karena plastik di dalam tanah yang tidak dapat diurai, akibatnya menghalangi lubang udara (Hendrastianto, 2019).

Plastik merupakan bahan yang mudah terbakar. Sehingga meningkatkan risiko kebakaran dan asap dari hasil pembakaran plastik yang sangat berbahaya karena mengandung gas-gas beracun seperti karbon monoksida (CO) dan hidrogen sianida ( $\mathrm{HCN}$ ). Hal ini dapat menimbulkan pencemaran udara. Keuntungan plastik meliputi: (1) Memiliki massa jenis 0,9 s.d $2 \mathrm{gram} / \mathrm{cm}^{2}$; (2) Tahan terhadap bahan kimia seperti asam, basa, dan garam; (3) Sebagai isolasi terhadap arus listrik; (4) Sebagai isolasi terhadap panas; (5) Mudah dilakukan proses produksi seperti dirol, dipres, dan dituang; (6) mempunyai permukaan yang padat dan halus serta mudah diwarnai; (7) Pembuatannya relatif murah. Sedangkan kerugian plastik meliputi: (1) Sifat kekuatannya rendah; (2) Sifatnya tahan panasnya kurang; (3) Sifat muai panasnya besar; (4) Sifat kekerasannya kurang dan tidak tahan goresan; (5) Mudah retak pada suhu kamar; dan (6) Daya penyerapan airnya relatif tinggi.

Plastik yang sudah tidak dipakai disebut dengan istilah limbah plastik atau sampah plastik (Pivnenko et al., 2016). Sampah plastik di Indonesia mencapai 64 juta ton/tahun dan sampah plastik yang dibuang ke laut 3,2 juta ton serta kantong plastik yang dibuang di lingkungan 10 miliar lembar/ tahun atau 85.000 ton (Era.id, 2019). Sampah plastik yang dibuang ke sungai akan mengakibatkan sungai menjadi dangkal dan menimbulkan penyumbatan aliran sungai dari hulu sampai hilir seperti yang dapat dilihat pada Gambar 1.
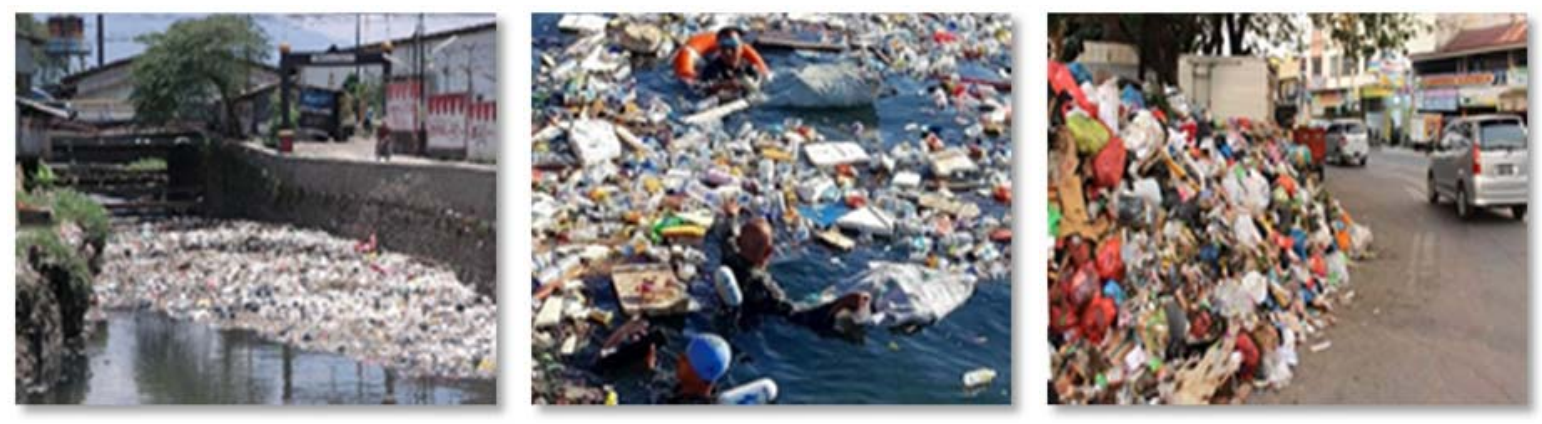

Gambar 1. Pembuangan sampah plastik di sungai (Yulianingsih, 2017)

Gambar 2. Pembuangan sampah plastik di laut (Sofuroh, 2019)

Gambar 3. Pembuangan sampah plastik di jalan raya (Syahrul, 2018)

Sampah plastik tidak hanya dijumpai di wilayah darat atau sungai, tetapi juga sudah menyebarluas ke wilayah laut yang luasnya sudah mencapai dua pertiga dari total luas Indonesia (Ambari, 2018). Sampah plastik yang dibuang ke laut disebabkan oleh pengelolaan sampah yang kurang efektif dan perilaku buruk dari masyarakat pesisir. Sampah plastik tidak hanya berdampak buruk terhadap 
ABDIMAS: Jurnal Pengabdian Masyarakat Universitas Merdeka Malang

Volume 6, No. 2, May 2021: 176-185

lingkungan, tetapi juga merugikan dari sisi ekonomi karena pendapatan negara dari sektor kelautan juga menurun. Sampah plastik yang dibuang ke laut juga akan mengancam keberadaan biota laut yang jumlahnya sangat banyak dan beragam serta di sisi lain sampah plastik bersama mikro plastik yang ada di laut juga dapat mengancam kawasan pesisir (Nazriati et al., 2020). Pembuangan sampak plastik di laut dapat dilihat pada Gambar 2.

Sampah plastik merupakan jenis sampah anorganik yang memiliki sifat berlawanan dengan sampah organik. Sampah anorganik merupakan sampah yang dihasilkan dari bahan-bahan non hayati baik produk sintetik maupun hasil proses teknologi pengolahan bahan tambang atau sumber daya alam dan tidak dapat diurai oleh alam seperti: kain, filter rokok, baju kaos, bola lampu, pulpen, spidol, kabel, ban, karet, plastik, sterofoam, kaca, logam, tissue, kertas, karton, buku, koran, majalah dan kaleng. Sampah anorganik termasuk bahan yang tidak ramah lingkungan dan waktu yang dibutuhkan sangat lama agar dapat terurai (Megawan \& Suryawan, 2019), sehingga pengolahan sampah anorganik diperlukan penanganan secara serius. Sampah plastik yang dibuang sembarangan dipinggir jalan raya akan menimbulkan bau, sehingga mengganggu kesehatan bagi pengguna jalan dan juga mengganggu tingkat kesuburan tanah semakin menurun. Pembuangan sampah plastik di jalan raya dapat dilihat pada Gambar 3.

Untuk mengatasi permasalahan di atas, pemerintah akan menerapkan cukai plastik sebesar Rp200,-/lembar atau Rp30.000,-/kg mulai tahun 2020. Kebijakan tersebut, dinilai menjadi salah satu solusi untuk menekan volume sampah di Indonesia yang mencapai 64 juta ton per-tahun. Sekitar 15\% dari volume sampah plastik tersebut, adalah sampah plastik dan sebagian dari sampah plastik terbawa hingga ke laut, mencemari dan membahayakan kehidupan makhluk hidup dan ekosistem laut. (Widowati, 2019).

Kelurahan Rampal Celaket secara administratif membawahi 6 RW dan 35 RT dengan jumlah penduduk 6885 orang dan 1687 kepala keluarga. Wilayah sebelah utara berbatasan dengan Kelurahan Lowokwaru, timur Bunulrejo, selatan dan barat berbatasan dengan Kelurahan Samaan. Dengan jumlah penduduk yang besar dan luas lahan pekarangan rumah warga yang sempit maka potensi sampah plastik di lingkungan Kelurahan Rampal Celaket cukup signifikan. Untuk itu, Laboratorium Metalurgi Fisik Program Studi Teknik Mesin Fakultas Teknik Universitas Merdeka Malang bekerjasama dengan P2M IKIP Budi Utomo Malang (Mukarom et al.., 2017) melakukan penyuluhan (counseling) bagi masyarakat peduli sampah plastik Kelurahan Rampal Celaket Kecamatan Klojen Kota Malang. Berdasarkan hasil diskusi dengan masyarakat peduli sampah plastik Kelurahan Rampal Celaket Kecamatan Klojen Kota Malang dapat diidentifikasi tentang kebutuhan pengetahuan mengenai: (1) Jenis sampah plastik yang dapat didaur ulang; (2) Sifat polimer termoplastik dan polimer termosetting ; dan (3) Cara mengolah limbah plastik menjadi barang kerajinan tangan atau biji-biji plastik sebagai bahan sekunder pada pabrik plastik. Kegiatan penyuluhan tentang pemanfaatan limbah sampah ini dilakukan untuk meningkatkan kepedulian masyarakat (Anita \& Puspitasari, 2019; Arico \& Jayanthi, 2017; Sunarjo \& Yuniarti, 2017; Setiyawan, 2016). 


\section{METODE}

Kegiatan penyuluhan ini merupakan program pengabdian kepada masyarakat yang dilakukan di Kantor Kelurahan Rampal Celaket jalan Simpang Kesambon 8 B Kecamatan Klojen Kota Malang.

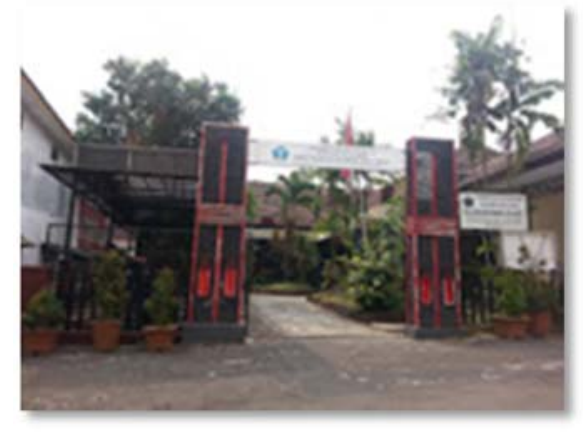

Gambar 4. Kantor Kelurahan Rampal Celaket jalan Simpang Kesambon 8 B Kecamatan Klojen Kota Malang

Penyuluhan yang disampaikan oleh pemateri menitikberatkan pada manjemen pengolahan limbah polimer termoplastik dengan pendekatan 2 (dua) metode meliputi: (1) Metode ceramah (lecture method) merupakan metode penyampaian materi penyuluhan bersifat kognitif kepada peserta penyuluhan. Kognitif merupakan potensi intelektual meliputi pengetahuan (knowledge), pemahaman (comprehention), penerapan (aplication), analisa (analysis), sintesa (sinthesis), dan evaluasi (evaluation); (2) Metode diskusi (discussion method) merupakan metode yang sangat erat hubungannya dengan pemecahan masalah (problem solving). Metode ini lazim disebut sebagai diskusi kelompok dan resitasi bersama. Metode tersebut dilakukan setelah selesai penyampaian materi melalui metode ceramah.

\section{HASIL DAN PEMBAHASAN}

Sebelum pelaksanaan penyuluhan dimulai, peserta penyuluhan melaksanakan her-registrasi (Gambar 5). Kegiatan ini diikuti oleh sekitar 25 orang ibu-ibu PKK di wilayah Kelurahan Rampal Celaket. Acara pembukaan disampaikan oleh perwakilan dari P2M IKIP Budi Utomo Malang bersama dengan tim pemateri dari Program Studi Teknik Mesin Fakultas Teknik Universitas Merdeka Malang (Gambar 6).
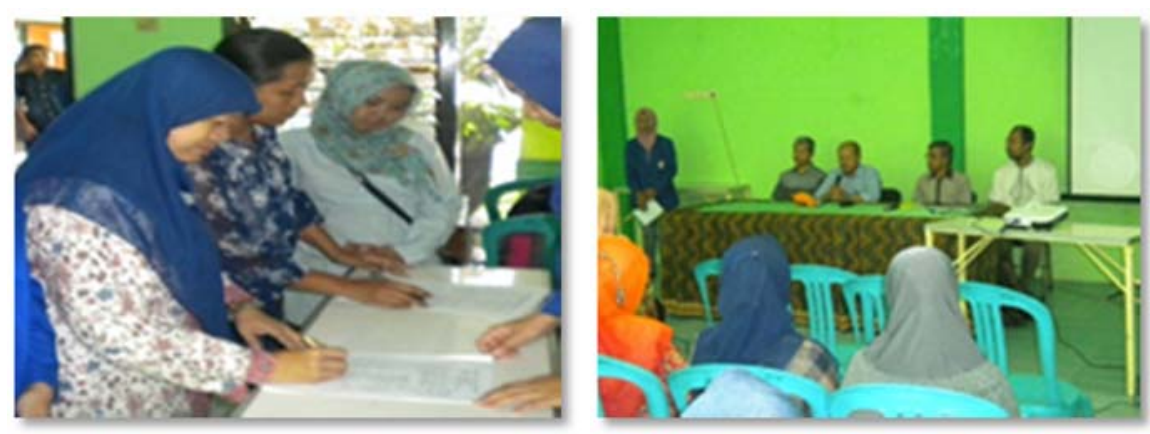

Gambar 5. Her-registrasi peserta penyuluhan

Gambar 6. Acara pembukaan oleh P2M IKIP Budi Utomo Malang dengan tim dosen Jurusan Teknik Mesin FT UNMER Malang 
ABDIMAS: Jurnal Pengabdian Masyarakat Universitas Merdeka Malang Volume 6, No. 2, May 2021: 176-185

Materi penyuluhan diberikan kepada peserta melalui ceramah (Gambar 7) tentang manajemen pengolahan limbah polimer termoplastik. Beberapa materi yang terkait dengan manajemen pengolahan sampah yang disampaikan antara lain: (1) Dampak sampah plastik terhadap lingkungan hidup; (2) Sifat polimer termoplastik dan polimer termosetting; (3) Cara mengolah limbah plastik menjadi barang kerajinan tangan atau biji-biji plastik sebagai bahan sekunder pada pabrik plastik. Setelah ceramah, kegiatan dilanjutkan dengan diskusi (Gambar 8) untuk menggali informasi tentang pemahaman peserta mengenai materi penyuluhan yang sudah disampaikan.
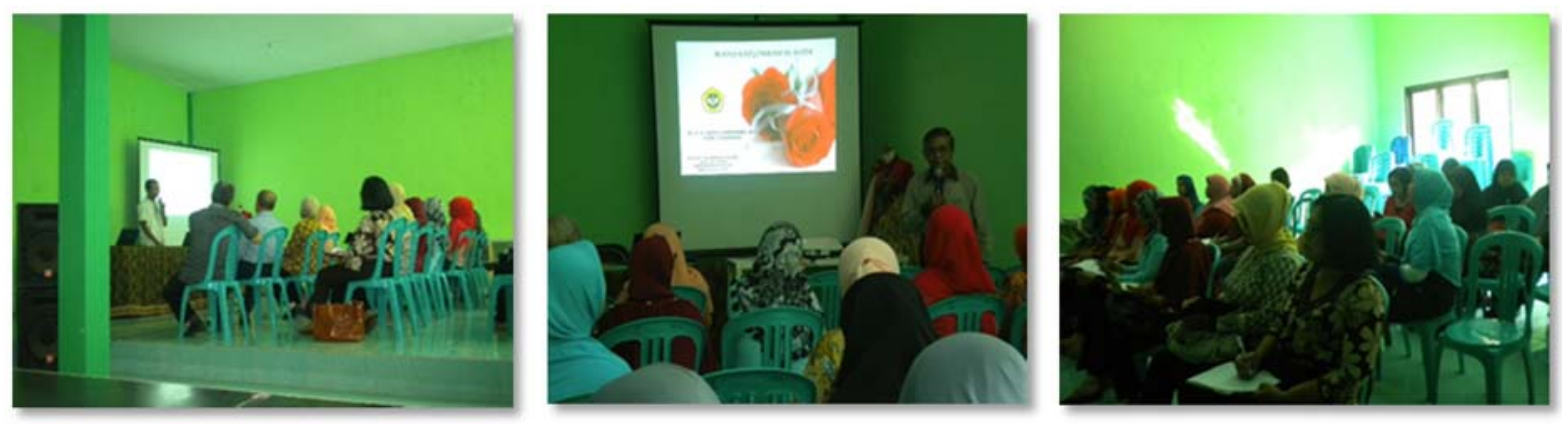

Gambar 7. Penyampaian materi penyuluhan melalui metode ceramah

Gambar 8. Kegiatan diskusi dengan peserta

Beberapa hal tentang manajemen pengelolaan sampah disampaikan sebagai materi penyuluhan yang berlangsung.

\section{Dampak sampah plastik terhadap lingkungan hidup}

Sampah plastik yang dibuang ke sungai, laut, daratan atau sembarangan akan menjadi beban lingkungan hidup. Beberapa dampak sampah plastik terhadap lingkungan hidup (Sukarmin \& Azizah, 2004) meliputi: (1) Tanah, air tanah, air sungai, air laut, air danau, air tambak ikan, makhluk hidup di dalam tanah akan tercemar; (2) Racun-racun dari partikel plastik yang meresap ke dalam tanah akan membunuh macam-macam hewan pengurai di dalam tanah; (3) PCB (polychlorinated biphenyl) yang tidak terurai walaupun sudah termakan oleh hewan dan tumbuh-tumbuhan akan menjadi racun berantai sesuai urutan makanannya termasuk manusia; (4) Sampah plastik mengganggu jalur penyerapan air ke dalam tanah; (5) Menurunan kesuburan tanah, hal ini dikarenakan plastik menghalangi sirkulasi udara di dalam tanah dan ruang gerak makhluk hidup bawah tanah yang berperan dalam proses penyuburan tanah; (6) Sampah plastik sulit diurai, mempunyai umur panjang, dan ringan akan semakin mempermudah terbawa angin, sehingga mempunyai potensi mencemari lautan dan wilayah-wilayah lainnya secara bergantian; (7) Hewan-hewan terperangkap di dalam timbunan sampah plastk, sehingga akibatnya mati; (8) Hewanhewan laut seperti lumba-lumba, penyu, dan anjing laut menganggap sampah atau kantong plastik sebagai makanannya, sehingga akhirnya dapat mati dan tidak mampu mencernanya; (9) Hewan-hewan yang menelan sampah atau kantong plastik akan mati, maka sampah atau kantong plastik yang berada di dalam tubuhnya tidak akan hancur dan tetap utuh, sehingga akhirnya akan menjadi bangkai yang 
dapat meracuni hewan lainnya dan manusia yang berada di sekitarnya, hingga mencemari lingkungan dengan baunya yang biasanya busuk dan menyengat.

\section{Sifat polimer termoplastik dan polimer termosetting}

Jenis sampah plastik yang dibuang ke sungai, laut dan daratan dibedakan 2 (dua) macam meliputi polimer termoplastik dan polimer termosetting (Ramadhan et al., 2020). Polimer termoplastik (Ormondroyd \& Morris, 2018) mempunyai sifat antara lain: (1) Tidak tahan panas; (2) Dapat meleleh apabila dipanaskan; (3) Dapat membeku apabila didinginkan; (4) Fleksibel dan mudah diregangkan; (5) Mampu didaur ulang menjadi produk baru; (6) Mampu dilarutkan menggunakan zat pelarut yang sesuai; dan (7) Molekul penyusunnya bercabang-cabang. Jenis polimer termoplastik yang dapat dilakukan daur ulang atau dicetak lagi dengan proses pemanasan ulang (Tabel 1) (Rees, 1995). Sedangkan polimer polimer thermosetting (Crawford \& Martin, 2020) mempunyai sifat: (1) Keras dan kaku; (2) Mengeras apabila dipanaskan; (3) Tidak dapat didaur ulang; (4) Tidak dapat larut dalam berbagai macam jenis pelarut; (5) Dapat meleleh apabila dipanaskan; (6) Tahan terhadap asam basa; dan (7) Mempunyai ikatan silang antar rantai molekul (Menges et al., 2001).

Tabel 1. Macam-macam polimer termoplastik yang dapat didaur ulang

\begin{tabular}{l}
\hline \multicolumn{1}{c}{ Polimer Termoplastik yang Dapat Didaur Ulang } \\
\hline Acrylic (Perspex) \\
Polyethylene (Polythene) \\
Polypropylene, Poly Vinyl Acetate (PVA) \\
Poly Vinyl Chloride (PVC) \\
Polystyrene dan ABS \\
PTFE (Teflon) \\
\hline
\end{tabular}

Struktur polimer termoplastik tidak mempunyai ikatan silang, melainkan hanya terdiri dari molekul-molekul rantai lurus atau bercabang (Gambar 9), sehingga mudah direnggangkan dan mudah meleleh, sedangkan struktur polimer thermosetting terdiri dari ikatan antar rantai yang kuat, sehingga sifatnya keras dan sulit meleleh (Gambar 10).

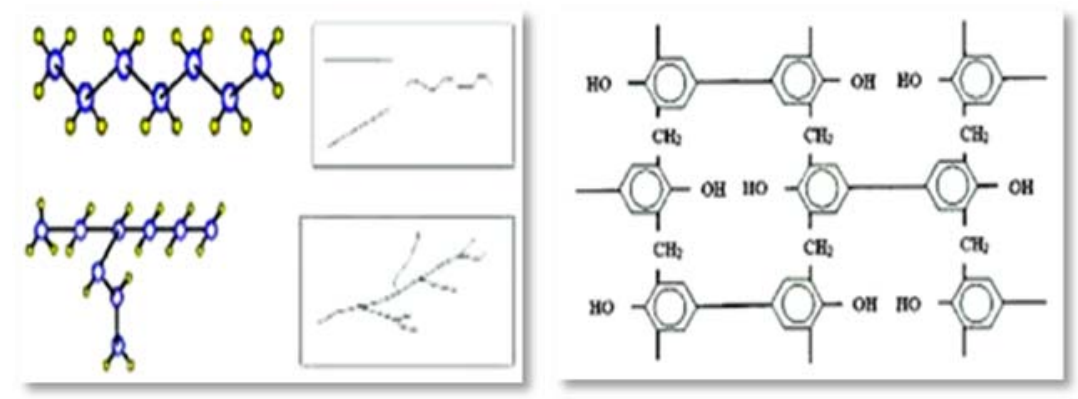

Gambar 9. Struktur bercabang polimer termoplastik

Gambar 10. Struktur ikatan silang polimer termosetting 
ABDIMAS: Jurnal Pengabdian Masyarakat Universitas Merdeka Malang

Volume 6, No. 2, May 2021: 176-185

\section{Cara mengolah limbah plastik menjadi barang kerajinan tangan atau biji-biji plastik sebagai bahan sekunder pada pabrik plastik}

Limbah plastik merupakan material bukan logam yang dapat di daur ulang untuk menjadi produk kerajinan tangan (Ramadhan et al., 2020) atau bahan sekunder berbentuk biji-biji plastik (Susana \& Darsono, 2016) dan selanjutnya diolah kembali pada pabrik plastik menjadi produk dengan ukuran dan bentuk sesuai dengan kebutuhan pasar. Proses daur ulang meliputi produk kerajinan tangan dan produk setengah jadi berbentuk biji-biji plastik sebagai bahan dasar sekunder di pabrik plastik (Baird, 1982). Langkah-langkah untuk membuat produk kerajinan tangan dengan bahan limbah polimer termoplastik secara manual (Gambar 11).
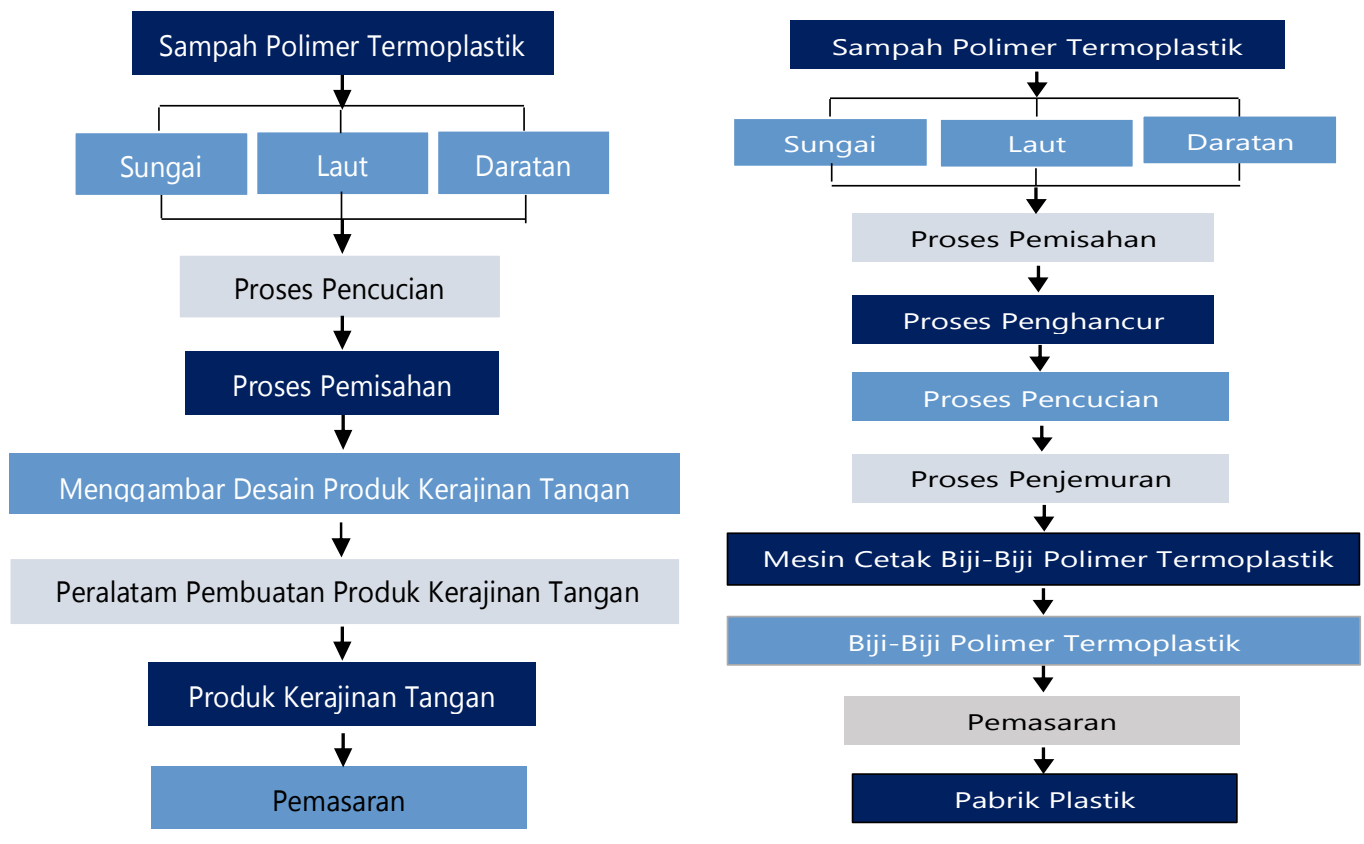

Gambar 11. Proses pengolahan limbah polimer termoplastik secara manual Gambar 12. Proses pengolahan limbah polimer termoplastik menggunakan TTG

Limbah polimer termoplastik (Gambar 11) sebelum dilakukan proses pemisahan dilakukan proses pencucian dalam bejana berisi air dengan tujuan menghilangkan kotoran-kotoran yang menempel pada dinding limbah polimer termoplastik. Limbah polimer termoplastik yang telah dicuci dijemur dan selanjutnya dilakukan proses pemisahan jenis limbah polimer termoplastik, sehingga mempermudah untuk melakukan pembuatan kerajinan tangan (Singh et al., 2017) seperti keranjang belanja, tempat tissue, vas bunga, pot bunga, hiasan dinding, dan payung. Peralatan yang digunakan untuk membuat kerajinan tangan seperti gunting, palu, tang, pisau dapur, tali, benang, spidol, cat, penggaris, dan kawat. Langkah-langkah proses pengolahan limbah polimer termoplastik dengan cara lain menggunakan mesin Teknologi Tepat Guna (TTG) (Gambar 12). Untuk mengolah limbah polimer termoplastik agar hancur, diperlukan mesin penghancur yang berfungsi untuk pencacah atau perajang dari berbagai macam bentuk, ukuran dan warna limbah polimer termoplastik seperti: botol, galon, gelas, kantong kresek, 
batangan dan lembaran (Gambar 13).

Limbah polimer termoplastik yang sudah hancur selanjutnya diolah kembali menjadi bijibiji plastik. Limbah plastik yang sudah hancur selanjutnya diolah kembali menjadi biji-biji plastik menggunakan mesin cetak (Gambar 14). Limbah polimer termoplastik yang sudah berbentuk biji-biji plastik (Gambar 15), selanjutnya dilakukan proses pencucian dengan tujuan menghilangkan kotorankotoran menggunakan mesin pencuci (Gambar 16). Limbah polimer termoplastik yang sudah berbentuk biji-biji plastik, selanjutnya dilakukan proses pencucian dengan tujuan menghilangkan kotoran-kotoran menggunakan mesin pencuci (Gambar 16).
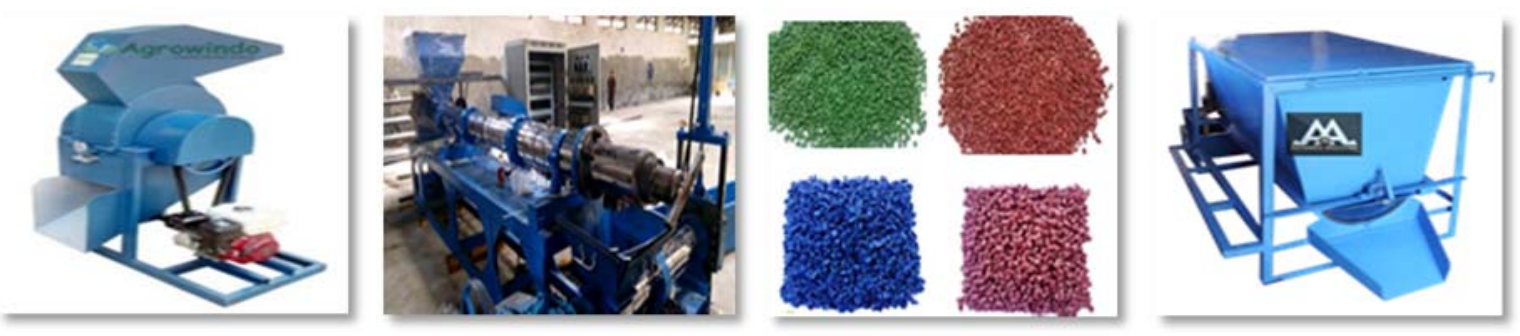

Gambar 13. Mesin penghancur limbah plastik

Gambar 14. Mesin cetak biji-biji plastik

Gambar 15. Biji-biji limbah polimer termoplastik Gambar 16. Mesin pencuci biji-biji plastik

Setelah kegiatan penyuluhan, peserta juga diberi kesempatan untuk mengikuti pelatihan dalam pembuatan beberapa produk dengan memanfaatkan limbah plastik. Ada tiga macam produk yang dibuat dengan memanfaatkan limbah plastik dalam pelatihan ini, yaitu tas, vas bunga, dan pigura. Pelatihan ini memberikan pengetahuan dan ketrampilan baru sebagai implementasi manajemen pengolahan sampah plastik kepada peserta (Gambar 17).
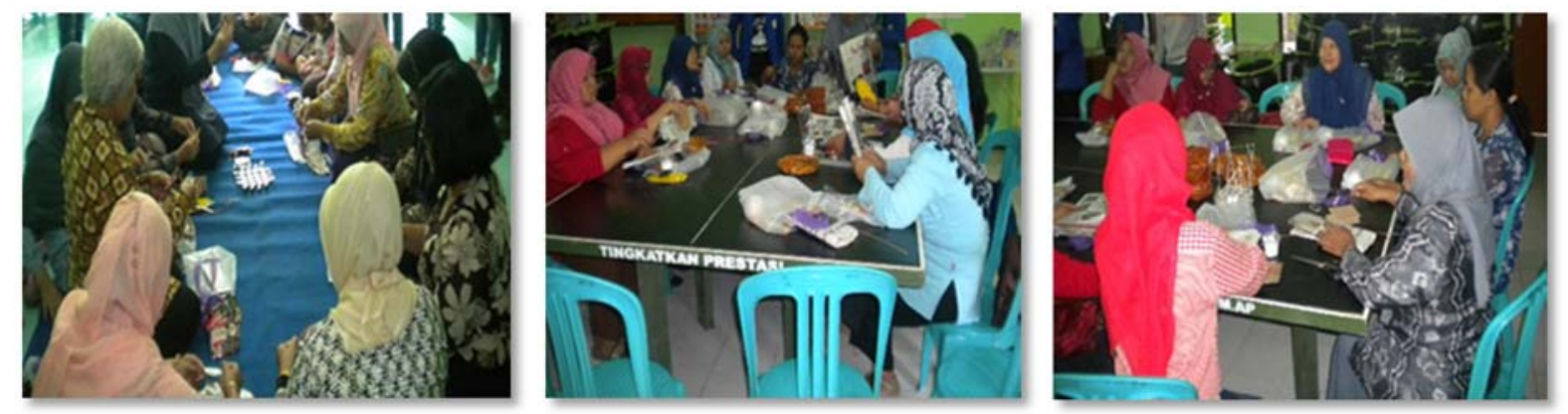

Gambar 17. Kegiatan pelatihan membuat aneka produk kerajinan tangan berbahan limbah plastik

\section{SIMPULAN DAN SARAN}

Penyuluhan yang dilakukan dengan metode ceramah dan diskusi dapat meningkatkan pengetahuan dan kesadaran masyarakat tentang pengolahan sampah polimer termoplastik. 
ABDIMAS: Jurnal Pengabdian Masyarakat Universitas Merdeka Malang

Volume 6, No. 2, May 2021: 176-185

Mengurangi limbah sampah polimer termoplastik tidak dapat hanya dilakukan dengan melakukan proses daur ulang, tetapi perlu dilakukan kajian tentang penggunaan bahan dasar untuk pembuatan produk plastik dengan kandungan gas-gas racun seperti karbon monoksida (CO) dan hidrogen sianida ( $\mathrm{HCN}$ ) yang rendah.

\section{DAFTAR PUSTAKA}

Ambari, M. (2018, Juli 26). Ancaman Sampah Plastik untuk Ekosistem Laut Harus Segera Dihentikan, Bagaimana Caranya? [Berita Online]. Mongabay: Situs Berita Lingkungan. Retrieved from: https://www.mongabay.co.id/2018/07/26/ancaman-sampah-plastik-untuk-ekosistem-lautharus-segera-dihentikan-bagaimana-caranya/

Anita, R. R., \& Puspitasari, C. (2019). Penerapan olahan limbah kantong plastik dengan teknik crochet sebagai unsur dekoratif pada produk fesyen. ATRAT: Jurnal Seni Rupa, 7(1), 81-91.

Arico, Z., \& Jayanthi, S. (2017). Pengolahan limbah plastik menjadi produk kreatif sebagai peningkatan ekonomi masyarakat pesisir. Martabe: Jurnal Pengabdian Kepada Masyarakat, 1(1), 1-6. http://dx.doi.org/10.31604/jpm.v1i1.1-6

Baird, R. J. (1982). Industrial Plastics. New York: The Goodheart-Willcox Company Inc.

Crawford, R. J., \& Martin, P. J. (2020). Plastics Engineering (4th ed.). Oxford: Butterworth-Heinemann.

Era.id. (2019, Juni 26). Jerat Mudarat Sampah Plastik [Berita Online]. Era.id. Retrieved from: https://era.id/afair/22628/jerat-mudarat-sampah-plastik

Hendrastianto, Z. A. (2019). Plastik: Pengertian, Sejarah, Jenis, Proses Pembuatan, dan Bahan Baku [Artikel Web]. ForesterAct. Retrieved from: https://foresteract.com/plastik/

Malcolm, P. S. (2001). Polymer Chemistry: An Introduction. (trans: Lis Sopyan). Jakarta: PT Pradnya Paramita.

Megawan, M. B., \& Suryawan, I. B. (2019). Pengelolaan sampah di daya tarik wisata Pantai Candikusuma, Desa Candikusuma, Kecamatan Melaya, Kabupaten Jembrana. Jurnal Destinasi Pariwisata, 7(2), 239-244. https://doi.org/10.24843/JDEPAR.2019.v07.i02.p05

Menges, G., Michaeli, W., \& Mohren, P. (2001). How to Make Injection Molds (3rd ed.). Munich: Hanser Publisher.

Mukarom, M., Sucipto, A., Afrida, I. R., Andriyono, R. D., Rusdi, R., \& Sufiyanto, S. (2017). Ipteks bagi Wilayah (IBW) di Kecamatan Klojen Kota Malang. JPM Pambudi, 1(1), 20-27.

https://doi.org/10.33503/pambudi.v1i1.3

Nazriati, N., Utomo, Y., Fajaroh, F., Suharti, S., Danar, D., \& Ciptawati, E. (2020), Pelatihan gerakan bersih-bersih Pantai Balekambang dari sampah plastik. Abdimas: Jurnal Pengabdian Masyarakat Universitas Merdeka Malang, 5(2), 139-144. https://doi.org/10.26905/abdimas.v5i2.3573

Odian, G. (1991). Principles of Polymerization (3 ${ }^{\text {rd }}$ ed.). New York: John Wiley \& Sons Inc.

Ormondroyd, G. A., \& Morris, A. F. (2018). Designing with Natural Materials. Florida: CRC Press.

Pivnenko, K., Eriksen, M. K., Martín-Fernández, J. A., Eriksson, E., \& Astrup, T. F. (2016). Recycling of plastic waste: Presence of phthalates in plastics from households and industry. Waste Management, 54, 44-52. https://doi.org/10.1016/j.wasman.2016.05.014 
Ramadhan, A., Lelo, L., \& Rasyid, R., (2020), Pelatihan pemanfaatan sampah plastik sebagai material produk hiasan bagi lulusan SMA di Kota Tangerang. Abdimas: Jurnal Pengabdian Masyarakat Universitas Merdeka Malang, 5(1), 1-17. https://doi.org/10.26905/abdimas.v5i1.3083

Rees, H. (1995). Mold Engineering. Ohio: Hanser Gardner Publications Inc.

Setiyawan, A. (2016). Gambaran kadar glukosa darah sewaktu pada petugas aviation security Bandara Juwata Tarakan dengan indeks massa tubuh 17-27 kg/m2. JKM: Jurnal Kesehatan Masyarakat, 4(3), 60-64.

Singh, N., Hui, D., Singh, R., Ahuja, I. P. S., Feo, L., \& Fraternali, F. (2017). Recycling of plastic solid waste: A state of the art review and future applications. Composites Part B: Engineering, 115, 409-422. https://doi.org/10.1016/j.compositesb.2016.09.013

Sofuroh, F. U. (2019, November 26). Bahaya Sampah Plastik di Laut: Bisa Cemari Ikan Konsumsi. detikNews. Retrieved from: https://news.detik.com/berita/d-4798953/bahaya-sampah-plastikdi-laut-bisa-cemari-ikan-konsumsi

Sukarmin, S., \& Azizah, U. (2004). Polimer. Bagian Proyek Pengembangan Kurikulum Direktorat Pendidikan Menengah Kejuruan Direktorat Jenderal Pendidikan Dasar dan Menengah Departemen Pendidikan Nasional 2000.

Sunarjo, S., \& Yuniarti, S. (2017). Pemanfaatan sayur buangan untuk pakan cacing African Night Crawler (ANC) sebagai bahan pembuat pellet. Abdimas: Jurnal Pengabdian Masyarakat Universitas Merdeka Malang, 2(1), 43-49. https://doi.org/10.26905/abdimas.v2i1.1290

Syahrul, J. (2018, Februari 20). Mengintip Kota-kota Gudang Sampah di Indonesia. Cakaplah. Retrieved from: $\quad$ https://www.cakaplah.com/berita/baca/17343/2018/02/20/mengintip-kotakotagudang-sampah-di-indonesia\#sthash.OC3yYoql.aGHZaGz3.dpbs

Susana, E., Darsono, J. T., (2016), Program pemberdayaan kesejahteraan keluarga melalui pendirian unit bank sampah di Kota Malang. Jurnal Ekonomika, Koordinasi Perguruan Tinggi Swasta (KOPERTIS) Wilayah VII, 9(1), 1-5.

Widowati, H. (2019, Oktober 31). Kebijakan Cukai Plastik Tak Pecahkan Masalah Sampah di Indonesia [Berita Online]. Katadata. Retrieved from: https://katadata.co.id

Yulianingsih, Y. (2017, Mei 17). Pencemaran Sungai Winongo Yogyakarta Masuk Kategori Berat [Berita Online]. Republika. Retrieved from: https://nasional.republika.co.id/berita/nasional/ daerah/1\%207/05/17/oq3fu7280 -pencemaran-sungai-winongo-yogyakarta-masuk-kategoriberat 